\title{
MENGARTIKULASIKAN TABEL INPUT-OUTPUT DAN KERANGKA ANALISISNYA
}

\author{
Budi Cahyono ; Bagus Sumargo2
}

\begin{abstract}
Input -Output (I-O) table can be used to analyse economic projection and present some service and good transactions in production activities, final demand, and bruto added value (BAV). I-O table can help to analyse government policy, such as impact analysis to output, bruto added value, and worker needed.
\end{abstract}

Keywords: Input -Output table, economic projection, government policy

\begin{abstract}
ABSTRAK
Tabel Input -Output merupakan alat yang efektif untuk analisis dan proyeksi perekonomian dalam suatu perencanaan pembangunan. Tabel tersebut menyajikan informasi transaksi barang dan jasa yang digunakan dalam kegiatan produksi, permintaan akhir dari komponen penyediaan (supply), dan Nilai Tambah Bruto (NTB). Analisis lanjutan berdasarkan tabel ini adalah analisis dampak dari suatu kebijakan pemerintah terhadap output, NTB, dan kebutuhan jumlah tenaga kerja.
\end{abstract}

Kata kunci: Tabel Input -Output, proyeksi perekonomian, kebijakan pemerintah

\section{PENDAHULUAN}

\footnotetext{
${ }^{1}$ Peneliti BPS

${ }^{2}$ Staf pengajar FMIPA, UBiNus, Jakarta dan Peneliti BPS
} 
Tabel Input -Output pada dasarnya hanyalah merupakan suatu sistem pencatatan ganda (double entry system) dari neraca transaksi yang terjadi antarprodusen dalam suatu perekonomian. Tabel Input -Output sebagai sistem penyajian data, sebenarnya telah mulai dikembangkan pada dekade 1930-an oleh Profesor Wasilly Leontief. Tabel Input -Output (IO) Indonesia disusun dengan maksud untuk menyajikan gambaran tentang hubungan timbal balik dan saling keterkaitan antarsatuan kegiatan (sektor) dalam perekonomian di Indonesia secara menyeluruh. Bentuk penyajian Tabel I-O adalah matriks dan masing-masing barisnya menunjukkan bagaimana output suatu sektor dialokasikan untuk memenuhi permintaan antara dan permintaan akhir sedangkan masing-masing kolomnya menunjukkan pemakaian input antara dan input primer oleh suatu sektor dalam proses produksinya.

Penyusunan Tabel I-O selain mampu menghasilkan alat yang efektif untuk analisis dan proyeksi perekonomian dalam suatu perencanaan pembangunan, dapat juga dijadikan landasan untuk menilai dan mengetahui berbagai kelemahan data statistik lainnya. Dengan demikian, hasil dari penyusunan suatu Tabel I-O selanjutnya dapat dimanfaatkan dalam usaha penyempurnaan sistim perstatistikan nasional.

\section{Pengertian Dasar Tabel Input -Output}

Tabel I-O pada dasarnya merupakan uraian statistik dalam bentuk matriks yang menyajikan informasi tentang transaksi barang dan jasa serta saling keterkaitan antara sektor yang satu dengan sektor lainnya, dalam suatu wilayah pada suatu periode waktu tertentu. Dengan Tabel I-O dapat dilihat bagaimana output dari suatu sektor ekonomi didistribusikan ke sektor lainnya dan bagaimana pula suatu sektor memperoleh input yang diperlukan dari sektor lainnya. Dalam suatu model Input -Output yang bersifat terbuka dan statis, transaksi yang digunakan dalam penyusunan Tabel Input -Output harus memenuhi tiga asumsi atau prinsip dasar berikut.

1. Keseragaman (homogeneity), yaitu asumsi bahwa setiap sektor hanya memproduksi satu jenis output (barang dan jasa) dengan struktur input tunggal (seragam) dan tidak ada substitusi otomatis antar output dari sektor yang berbeda.

2. Kesebandingan (proportionality), yaitu asumsi bahwa kenaikan penggunaan input oleh suatu sektor akan sebanding dengan kenaikan output yang dihasilkan.

3. Penjumlahan (additivity), yaitu asumsi bahwa jumlah pengaruh kegiatan produksi di berbagai sektor merupakan penjumlahan dari pengaruh pada masing-masing sektor tersebut.

Untuk memperoleh gambaran tentang bagaimana suatu Tabel I-O disusun, pada Tabel 1 disajikan contoh Tabel I-O untuk sistem perekonomian yang terdiri dari tiga sektor produksi, yaitu sektor 1, 2, dan 3 .

Tabel 1 Tabel Input -Output untuk Sistem Perekonomian dengan Tiga Sektor Produksi 


\begin{tabular}{|c|c|c|c|c|c|c|c|}
\hline \multirow{2}{*}{\multicolumn{3}{|c|}{ Struktur Input }} & \multirow{2}{*}{\multicolumn{3}{|c|}{$\begin{array}{c}\text { Permintaan Antara } \\
\text { Sektor Produksi } \\
\end{array}$}} & \multirow{2}{*}{$\begin{array}{l}\text { Permintaan } \\
\text { Akhir }\end{array}$} & \multirow{2}{*}{ Jumlah } \\
\hline & & & & & & & \\
\hline \multirow{3}{*}{ Input Antara } & \multirow{3}{*}{$\begin{array}{l}\text { Sektor } \\
\text { Produksi }\end{array}$} & 1 & $\mathrm{x}_{11}$ & $\mathrm{x}_{12}$ & $\mathrm{x}_{13}$ & $\mathrm{~F}_{1}$ & $\mathrm{X}_{1}$ \\
\hline & & 2 & $\mathrm{x}_{21}$ & $\mathrm{x}_{22}$ & $\mathrm{x}_{23}$ & $\mathrm{~F}_{2}$ & $X_{2}$ \\
\hline & & 3 & $\mathrm{x}_{31}$ & $\mathrm{x}_{32}$ & $\mathrm{x}_{33}$ & $\mathrm{~F}_{3}$ & $X_{3}$ \\
\hline \multicolumn{3}{|c|}{ Input Primer } & $\mathrm{V}_{1}$ & $\mathrm{~V}_{2}$ & $\mathrm{~V}_{3}$ & & \\
\hline \multicolumn{3}{|c|}{ Jumlah Input } & $\mathrm{X}_{1}$ & $\mathrm{X}_{2}$ & $\mathrm{X}_{3}$ & & \\
\hline
\end{tabular}

Isian sepanjang baris pada Tabel 1 memperlihatkan bagaimana output dari suatu sektor dialokasikan, yaitu sebagian untuk memenuhi permintaan antara dan sebagian lainnya untuk memenuhi permintaan akhir. Isian sepanjang kolomnya menunjukkan pemakaian input antara dan input primer oleh suatu sektor. Berdasarkan cara pengisian angka ke dalam sistem matriks, dapat dilihat bahwa angka setiap sel pada tabel tersebut memiliki makna ganda. Angka dari suatu sel pada traksasi antara, misalnya $\mathrm{x}_{12}$, jika dilihat menurut baris maka angka tersebut menunjukkan besarnya output sektor 1 yang dialokasikan untuk memenuhi permintaan antara di sektor 2 . Jika dilihat menurut kolom maka $\mathrm{x}_{12}$ menunjukkan besarnya input yang digunakan oleh sektor 2 yang berasal dari sektor 1 .

Dari gambaran tersebut tampak bahwa penyusunan angka dalam bentuk matriks memperlihatkan suatu jalinan yang saling mengait dari berbagai kegiatan antarsektor. Sebagai ilustrasi, dapat diamati proses pengalokasian output pada Tabel 1. Output sektor 1 pada tabel tersebut adalah sebesar $\mathrm{X}_{1}$ dan didistribusikan sepanjang baris sebesar $\mathrm{x}_{11}, \mathrm{x}_{12}$, dan $\mathrm{x}_{13}$ masing-masing untuk memenuhi permintaan antara sektor 1, 2 dan 3, sedangkan sisanya sebesar $F_{1}$ digunakan untuk memenuhi permintaan akhir. Begitu juga dengan output sektor 2 dan 3 masing-masing sebesar $\mathrm{X}_{2}$ dan $\mathrm{X}_{3}$, dapat dilihat dengan cara yang sama dalam proses pengalokasian output sektor 1 . Alokasi output pada masing-masing sektor tersebut dalam bentuk persamaan aljabar dapat dituliskan sebagai berikut.

$$
\begin{aligned}
& \mathrm{x}_{11}+\mathrm{x}_{12}+\mathrm{x}_{13}+\mathrm{F}_{1}=\mathrm{X}_{1} \\
& \mathrm{x}_{21}+\mathrm{x}_{22}+\mathrm{x}_{23}+\mathrm{F}_{2}=\mathrm{X}_{2} \\
& \mathrm{x}_{31}+\mathrm{x}_{32}+\mathrm{x}_{33}+\mathrm{F}_{3}=\mathrm{X}_{3}
\end{aligned}
$$

Atau dalam bentuk persamaan umum dapat dituliskan sebagai berikut.

$$
\sum_{j=1}^{3} x_{i j}+F_{i}=X_{i} ; \quad \text { untuk semua } i=1,2,3 \ldots \ldots
$$

Keterangan:

$\mathrm{x}_{\mathrm{ij}}=$ output sektor $\mathrm{i}$ yang digunakan sebagai input sektor $\mathrm{j}$ 
$\mathrm{F}_{\mathrm{i}}=$ permintaan akhir terhadap sektor

$\mathrm{X}_{\mathrm{i}}=$ jumlah output sektor $\mathrm{i}$

Apabila angka dibaca menurut kolom, khususnya pada transaksi antara, maka angka pada kolom (sektor) tertentu menunjukkan berbagai input yang diperlukan dalam proses produksi pada sektor tersebut. Apabila Tabel 1 digunakan sebagai ilustrasi maka persamaan aljabar untuk input yang digunakan oleh masing-masing sektor dapat dituliskan sebagai berikut.

$$
\begin{aligned}
& \mathrm{x}_{11}+\mathrm{x}_{21}+\mathrm{x}_{31}+\mathrm{V}_{1}=\mathrm{X}_{1} \\
& \mathrm{x}_{12}+\mathrm{x}_{22}+\mathrm{x}_{32}+\mathrm{V}_{2}=\mathrm{X}_{2} \\
& \mathrm{x}_{13}+\mathrm{x}_{23}+\mathrm{x}_{33}+\mathrm{V}_{3}=\mathrm{X}_{3}
\end{aligned}
$$

Atau dalam bentuk persamaan umum dapat dituliskan sebagai berikut.

$$
\sum_{i=1}^{3} x_{i j}+V_{j}=x_{j} \text {; untuk semua } j=1,2,3 \ldots(1.4)
$$

Keterangan:

$\mathrm{V}_{\mathrm{j}}=$ nilai tambah atau input primer sektor $\mathrm{j}$.

Persamaan tersebut merupakan persamaan dasar yang sangat penting. khususnya untuk melakukan analisis perekonomian dengan model input-output.

\section{Klasifikasi Sektor}

Tabel I-O adalah suatu sistem penyajian data perekonomian yang menyeluruh. Oleh karena itu, suatu Tabel I-O dituntut untuk mampu mencakup seluruh komoditi dan kegiatan perekonomian, baik komoditi yang dihasilkan oleh sektor produksi dalam negeri (domestik) maupun komoditi yang berasal dari produksi luar negeri (impor). Pada kenyataannya, barang dan jasa atau komoditi yang dihasilkan oleh sektor produksi dapat terdiri dari berbagai jenis dan bentuk fisik yang sangat beragam. Akibatnya, jika setiap barang dan jasa yang berbeda tersebut dimunculkan sebagai satu sektor tersendiri maka proses penyusunan Tabel I-O akan menjadi sangat rumit. Oleh karena itu, dalam proses penyusunan Tabel I-O, diperlukan suatu tahapan untuk mengelompokkan barang dan jasa ke dalam kelompok tertentu. Proses pengelompokan barang dan jasa inilah yang dikenal sebagai proses klasifikasi sektor. Dalam praktik penyusunan Tabel I-O, klasifikasi sektor harus dilakukan pada tahap awal.

Untuk menyusun klasifikasi sektor, sifat dan jenis setiap komoditi yang ada harus dipelajari dengan seksama. Perlu diperhatikan dalam hal ini antara lain adalah teknologi pembuatan dan prospek masa depan dari peranan dan kegunaan setiap komoditi dalam 
kegiatan prekonomian secara menyeluruh. Jika penyusunan klasifikasi sektor dibuat semakin rinci maka akan lebih mendalam pula pengenalan terhadap anatomi fisik berbagai barang dan jasa yang dicakup oleh masing-masing sektor. Oleh karena itu, proses peyusunan klasifikasi sektor selain dapat mempermudah pekerjaan penyusunan Tabel I-O, dapat pula dimanfaatkan dalam melakukan analisis. Di samping itu, klasifikasi sektor juga sangat diperlukan sebagai dasar dalam penyusunan konversi dari suatu sistem ke sistem lainnya.

Selain untuk keperluan Tabel I-O, sebenarnya telah banyak pula klasifikasi yang disusun untuk keperluan lain, baik pada tingkat nasional maupun internasional. Klasifikasi tersebut jenisnya tergantung dari bidang yang menggunakannya, seperti klasifikasi jabatan, klasifikasi lapangan usaha, klasifikasi komoditi, klasifikasi tarif ekspor-impor, dan sebagainya. Prinsip utama dalam penyusunan klasifikasi sektor adalah keseragaman (homogenitas) dari setiap kelompok/sektor. Maksudnya, barang dan jasa atau kegiatan perekonomian yang dicakup oleh suatu sektor harus memiliki sifat yang relatif homogen/seragam. Klasifikasi sektor yang diperlukan untuk Tabel I-O adalah suatu klasifikasi yang mampu merekam semua aspek yang berkaitan dengan kegiatan produksi dan distribusi barang dan jasa. Oleh karena itu, penyusunan klasifikasi sektor untuk Tabel I-O harus memenuhi dua kriteria, yaitu (a) asas kesatuan komoditi dan (b) asas kesatuan kegiatan.

\section{Manfaat dan Kegunaan Tabel Input-Output}

Model I-O merupakan alat analisis yang lengkap dan komprehensif. Beberapa kegunaan tabel I-O, antara lain adalah memberikan analisis tentang hal berikut.

1. Struktur perekonomian nasional/regional yang mencakup struktur output dan nilai tambah (PDB) masing-masing sektor.

2. Komponen nilai tambah menurut jasa faktor produksi pada setiap sektor ekonomi.

3. Struktur input antara, yaitu penggunaan berbagai barang dan jasa oleh sektor produksi.

4. Struktur penyediaan barang dan jasa, baik berupa produksi dalam negeri maupun barang yang berasal dari impor.

5. Pola permintaan barang dan jasa baik permintaan antara oleh sektor produksi maupun permintaan akhir untuk konsumsi, investasi, dan ekspor.

6. Untuk memperkirakan dampak permintaan akhir terhadap output, nilai tambah, impor, penerimaan pajak, dan penyerapan tenaga kerja di berbagai sektor produksi.

7. Untuk menyusun proyeksi variabel ekonomi makro.

8. Untuk analisis perubahan harga, yaitu dengan melihat pengaruh secara langsung dan tidak langsung dari perubahan harga input terhadap harga output.

9. Untuk mengetahui sektor yang pengaruhnya paling dominan terhadap pertumbuhan ekonomi dan sektor yang peka terhadap pertumbuhan perekonomian nasional/regional.

10.Untuk melihat konsistensi dan kelemahan berbagai data statistik yang pada gilirannya dapat dijadikan sebagai landasan perbaikan, dan penyempurnaan.

\section{PEMBAHASAN}




\section{Analisis Deskriptif Tabel Input-Output}

\section{Analisis Struktur Input}

Analisis ini berguna untuk menjelaskan, misalnya besarnya (dalam persentase) nilai tambah yang dihasilkan oleh suatu sektor dibandingkan dengan total output sektor bersangkutan; Penggunaan input (antara) untuk menghasilkan output suatu sektor. Analisis ini diperoleh dengan cara menganalisis koefisien input suatu tabel I-O.

\section{Analisis Alokasi Output}

Analisis ini digunakan untuk menjelaskan penggunaan output suatu sektor oleh yang lain atau penggunaan output suatu sektor oleh permintaan antara dan permintaan akhir. Analisis ini diperoleh dengan cara menganalisis koefisien output suatu tabel I-O.

\section{Analisis PDB Menurut Penggunaan}

Analisis ini berguna untuk menjelaskan persentase pembentukan PDB suatu negara ditinjau dari sisi penggunaan, seperti konsumsi rumah tangga, konsumsi pemerintah, pembentukan modal tetap bruto, perubahan stok, dan ekspor (neto). Dengan analisis ini dapat diperoleh informasi mengenai kontribusi masing-masing komponen PDB tersebut terhadap total PDB.

\section{Analisis Kontribusi Sektor}

Analisis ini berguna untuk menjelaskan kontribusi sektor, misalnya terhadap total output, nilai tambah, pendapatan tenaga kerja, ekspor, dan impor. Dari hasil analisis ini dapat diperoleh informasi mengenai kontribusi masing-masing sektor terhadap masing-masing permasalahan yang ditelaah (misalnya sektor mana yang menghasilkan nilai tambah terbesar).

\section{Analisis Permintaan dan Penawaran}

Tabel I-O menyajikan komposisi keseimbangan antara permintaan (demand) dan penyediaan (supply) antarunit usaha di berbagai lapangan usaha. Penawaran produk barang dan jasa didapatkan dari output domestik dan barang impor dari luar wilayah. Sisi permintaan mencakup permintaan antara (intermediate demand) dan permintaan akhir (final demand) terhadap komoditi atau sektor usaha. 


\section{Analisis Dampak Output}


Dalam model I-O, output memiliki hubungan timbal balik dengan permintaan akhir dan output tersebut. Artinya, jumlah output yang dapat diproduksi tergantung dari jumlah permintaan akhirnya. Namun demikian dalam keadaan tertentu, output justru yang menentukan besarnya permintaan akhir. Output dalam model I-O dapat dihitung dengan rumus berikut.

$$
X_{F T}=(I-A)^{-1}(F-M) \quad \ldots \quad \text { (1) }
$$

Atau rumusan itu sekaligus mencerminkan bahwa pembentukan output $(X)$ dipengaruhi oleh permintaan akhir $(F-M)$ atau $F^{d}$.

$$
X_{\mathrm{FD}}=\left(I-A^{d}\right)^{-1} F^{d} \quad \ldots \quad \text { (2) }
$$

Output yang terbentuk sebagai akibat dari dampak seluruh permintaan akhir $\left(X_{F T}\right)$ akan sama dengan output yang terbentuk sebagai akibat permintaan akhir domestik $\left(X_{F D}\right)$. Dalam banyak analisis yang lebih sering digunakan adalah $X_{F D}$.. Penggunaan persamaan (1) dan (2) tersebut, antara lain untuk untuk menghitung porsi output yang terbentuk sebagai dampak dari masing-masing komponen permintaan akhir dan memperkirakan output yang terbentuk akibat dampak permintaan akhir yang diproyeksikan.

Persamaan (1) dan (2) yang masih bersifat umum tersebut dapat dirinci lagi menjadi beberapa formula sesuai dengan banyaknya komponen permintaan akhir, yaitu pengeluaran konsumsi rumah tangga (301), pengeluaran konsumsi pemerintah (302), pembentukan modal tetap (303), perubahan stok (304), dan ekspor barang dan jasa (305+306). Andaikan persamaan (2) digunakan dalam analisis maka pengembangannya akan menjadi lima buah formula sebagai berikut.

$X_{301}=\left(I-A^{d}\right)^{-1} F^{d}{ }_{301}$
$X_{302}=\left(I-A^{d}\right)^{-1} F^{d}{ }^{302}$
$X_{303}=\left(I-A^{d}\right)^{-1} F^{d^{303}}$
$X_{304}=\left(I-A^{d}\right)^{-1} F^{d}{ }_{304}$
$X_{305+306}=\left(I-A^{d}\right)^{-1 d}{ }_{305+306}$

Keterangan:

$$
X_{F D} \quad=X_{301}+X_{302}+X_{303}
$$




$$
\begin{array}{cc}
+X_{304}+X_{(305+306)} & \text { Output yang terbentuk akibat dampak pengeluaran konsumsi rumah } \\
X_{301} & \text { tangga }\left(F^{d}{ }_{301}\right) \\
& =\begin{array}{l}
\text { Output yang terbentuk akibat dampak pengeluaran konsumsi } \\
\text { pemerintah }\left(F^{d}{ }_{302}\right)
\end{array} \\
& =\begin{array}{c}
\text { Output yang terbentuk akibat dampak pembentukan modal tetap } \\
X_{303}
\end{array} \\
& \quad\left(F^{d}{ }_{303}\right)
\end{array}
$$

Untuk lebih memperjelas penggunaan persamaan (1) dan (2), berikut ini diuraikan contoh. Rincian nilai masing-masing komponen permintaan akhir dari tabel tersebut seperti pada Tabel 5 .

Tabel 5 Komponen Permintaan Akhir Transaksi Domestik

\begin{tabular}{ccccccc}
\hline \hline Sektor & 301 & 302 & 303 & 304 & $305+306$ & 309 \\
\hline$(1)$ & $(2)$ & $(3)$ & $(4)$ & $(5)$ & $(6)$ & $(7)$ \\
\hline 1 & 19 & 0 & 0 & 3 & 15 & 37 \\
2 & 44 & 1 & 5 & -1 & 28 & 77 \\
3 & 52 & 17 & 42 & 0 & 10 & 121 \\
\hline Jumlah & 115 & 18 & 47 & 2 & 53 & 235 \\
\hline \hline
\end{tabular}

Berdasarkan matriks kebalikan yang telah dihitung dan dengan persamaan (2) maka dampak permintaan akhir terhadap output dapat dihitung sebagai berikut.

$X=\left(I-A^{d}\right)^{-1} F^{d}$

$$
\begin{aligned}
X & =\left(\begin{array}{rrr}
1,0498 & 0,3491 & 0,1097 \\
0,0763 & 1,2391 & 0,2295 \\
0,0719 & 0,1694 & 1,2224
\end{array}\right) \times\left(\begin{array}{rrrrr}
19 & 0 & 0 & 3 & 15 \\
44 & 1 & 5 & -1 & 28 \\
52 & 17 & 42 & 0 & 10
\end{array}\right) \\
X & =\left(\begin{array}{rrrrr}
41,0 & 2,2 & 6,4 & 2,8 & 26,6 \\
67,9 & 5,1 & 15,8 & -1,0 & 38,1 \\
72,0 & 20,9 & 52,1 & 0,1 & 17,8
\end{array}\right)
\end{aligned}
$$

Hasil penghitungan tersebut dapat disajikan dalam bentuk Tabel seperti pada Tabel 6 
berikut.

Tabel 6 Output Domestik yang Dipengaruhi oleh Masing-Masing Komponen Permintaan Akhir

\begin{tabular}{crrrrrr}
\hline \hline Sektor & 301 & 302 & 303 & 304 & $305+306$ & Jumlah \\
\hline$(1)$ & $(2)$ & $(3)$ & $(4)$ & $(5)$ & $(6)$ & $(7)$ \\
\hline 1 & 41,0 & 2,2 & 6,4 & 2,8 & 26,6 & 79,0 \\
2 & 67,9 & 5,1 & 15,8 & $-1,0$ & 38,1 & 126,0 \\
3 & 72,0 & 20,9 & 52,1 & 0,1 & 17,8 & 163,0 \\
\hline Jumlah & 180,9 & 28,3 & 74,3 & 1,8 & 82,5 & 368,0 \\
\hline \hline
\end{tabular}

Berdasarkan Tabel 2 dapat dilihat bahwa output sektor 1 yang terbentuk sebagai akibat dari konsumsi rumah tangga (301) adalah sebesar 41,0; konsumsi pemerintah (302) sebesar 2,2; pembentukan modal tetap (303) sebesar 6,4; Perubahan stok (304) sebesar 2,8 dan ekspor barang dan jasa (305+306) sebesar 26,6. Pengaruh masing-masing komponen permintaan akhir terhadap output sektor 2 dan 3 dapat dilihat dengan cara yang sama seperti sektor 1. Jumlah setiap baris dari hasil penghitungan tersebut menunjukkan besarnya output yang terbentuk sebagai akibat dari permintaan akhir terhadap sektor yang bersangkutan.

Jika pengamatan dilakukan menurut kolom maka angka pada masing-masing kolom menunjukkan pengaruh masing-masing komponen permintaan akhir terhadap pembentukan output di masing-masing sektor. Sebagai misal, konsumsi rumah tangga (301) mengakibatkan pembentukan output di sektor 1, 2, dan 3 masing-masing sebesar 41,0; 67,9; dan 72,0. Dengan demikian, jumlah kolom 1 sebesar 180,9 menunjukkan besarnya output seluruh sektor perekonomian yang terbentuk sebagai akibat dari konsumsi rumah tangga. Cara pengamatan yang sama dapat dilakukan untuk komponen permintaan akhir lainnya.

\section{Analisis Dampak Nilai Tambah Bruto}

Nilai Tambah Bruto (NTB) adalah input primer yang merupakan bagian dari input secara keseluruhan. Sesuai dengan asumsi dasar yang digunakan dalam penyusunan tabel I$\mathrm{O}$, hubungan antara NTB dengan output bersifat linear. Artinya, kenaikan atau penurunan output akan diikuti secara proporsional oleh kenaikan dan penurunan NTB. Hubungan tersebut dapat dijabarkan dalam persamaan berikut.

Keterangan:

$$
\begin{aligned}
\mathrm{V} & =\text { matriks NTB } \\
\hat{\mathrm{V}} & =\text { matriks diagonal koefisien NTB } \\
\mathrm{X} & =\left(I-A^{d}\right)^{-1} F^{d} \text { atau }(I-A)^{-1} F \\
& \text { Isian sel diagonal } \hat{\mathrm{V}} \text { adalah NTB sektor yang bersangkutan dibagi dengan outputnya }
\end{aligned}
$$


sedangkan sel di luar diagonal adalah 0 . Jadi, bentuk matriks $\hat{\mathrm{V}}$ sebagai berikut.

$\hat{V}=\left(\begin{array}{ccccc}v_{1} & \ldots & 0 & \ldots & 0 \\ \vdots & & \vdots & & \vdots \\ 0 & \cdots & v_{i} & \ldots & 0 \\ \vdots & & \vdots & & \vdots \\ 0 & \ldots & 0 & \ldots & v_{n}\end{array}\right)$

dengan

$\hat{\mathrm{V}}_{\mathrm{i}}=\frac{\text { NTB sektor } \mathrm{i}}{\text { Output sektor } \mathrm{i}}$

Dari data pada Tabel 6 dapat disusun matriks NTB-nya sebagai berikut.

$\hat{V}=\left(\begin{array}{ccc}0,8608 & 0,0000 & 0,0000 \\ 0,0000 & 0,3413 & 0,0000 \\ 0,0000 & 0,0000 & 0,5951\end{array}\right)$

Oleh karena itu, berdasarkan $\mathbf{X}$ dari hasil penghitungan pada bagian 1 maka penciptaan NTB yang dipengaruhi oleh masing-masing komponen permintaan akhir sebagai berikut.

$V=\hat{V} X$

$V=\left(\begin{array}{rrrrr}35,3 & 1,9 & 5,5 & 2,4 & 22,9 \\ 23,2 & 2,8 & 5,4 & -0,3 & 13,0 \\ 42,9 & 12,5 & 31,0 & 0,0 & 10,6\end{array}\right)$

Penyajian dalam bentuk tabel dari hasil penghitungan tersebut dapat dilihat pada Tabel 7 . 
Tabel 7 Nilai Tambah Bruto yang Dipengaruhi Masing-Masing Komponen Permintaan Akhir

\begin{tabular}{ccccccc}
\hline \hline Sektor & 301 & 302 & 303 & 304 & $305+306$ & Jumlah \\
\hline$(1)$ & $(2)$ & $(3)$ & $(4)$ & $(5)$ & $(6)$ & $(7)$ \\
\hline 1 & 35,3 & 1,9 & 5,5 & 2,4 & 22,9 & 68,0 \\
2 & 23,2 & 2,8 & 5,4 & $-0,3$ & 13,0 & 43,0 \\
3 & 42,9 & 12,5 & 31,0 & 0,0 & 10,6 & 97,0 \\
\hline Jumlah & 101,3 & 16,2 & 41,9 & 2,1 & 46,5 & 208,0 \\
\hline \hline
\end{tabular}

Berdasarkan Tabel 7 dapat dilihat bahwa penciptaan NTB di sektor 1 yang dipengaruhi oleh konsumsi rumah tangga (301) adalah sebesar 35,3; konsumsi pemerintah (302) sebesar 1,9; pembentukan modal tetap (303) sebesar 5,5; perubahan stok (304) sebesar 2,4 dan ekspor barang dan jasa $(305+306)$ sebesar 22,9. Jumlah penciptaan NTB di sektor 1 sebesar 68,0 menunjukkan jumlah NTB yang diciptakan di sektor 1 yang dipengaruhi oleh seluruh komponen permintaan akhir. Untuk sektor 2 dan 3, pengamatannya dapat dilakukan dengan cara yang sama terhadap penciptaan NTB di sektor 1 .

Setiap kolom pada Tabel 7 menunjukkan pengaruh dari masing-masing komponen permintaan akhir terhadap proses penciptaan NTB di masing-masing sektor perekonomian. Angka di kolom 301, misalnya, menunjukkan bahwa pengaruh konsumsi rumah tangga terhadap penciptaan NTB di sektor 1, 2, dan 3 masing-masing adalah sebesar 35,3; 12,3; dan 42,9. Jumlah untuk kolom 301 sebesar 101,3 menunjukkan besarnya NTB dari seluruh sektor yang terbentuk sebagai akibat dari konsumsi rumah tangga. Dengan cara yang sama, selanjutnya dapat dilakukan pengamatan terhadap pengaruh masing-masing komponen permintaan akhir terhadap penciptaan NTB di masing-masing sektor.

\section{Analisis Dampak Kebutuhan Tenaga Kerja}

\section{Jumlah Tenaga Kerja Sektoral}

Dalam suatu proses produksi, tenaga kerja merupakan salah satu faktor produksi yang memiliki peranan cukup penting. Pengeluaran untuk tenaga kerja oleh produsen merupakan salah satu komponen input primer yang antara lain berupa upah dan gaji, tunjangan, dan bonus serta termasuk hasil usaha seperti sewa, bunga, keuntungan, baik berupa uang maupun barang. Definisi tenaga kerja dalam tabel I-O pada dasarnya sama dengan definisi yang digunakan dalam Sensus Penduduk, yaitu penduduk berumur 10 tahun ke atas yang bekerja dengan maksud memperoleh atau membantu memperoleh penghasilan, sekurang-kurangnya satu jam secara tidak terputus dalam seminggu yang lalu. Dalam banyak analisis makro tenaga kerja, sering juga disebut dengan kesempatan kerja atau lapangan kerja.

Data tenaga kerja yang ideal untuk keperluan analisis produktivitas dan efisiensi 
tenaga kerja adalah dengan satuan ekivalen tenaga kerja penuh. Namun demikian, data tenaga kerja yang tersedia sampai saat ini ternyata belum memungkinkan untuk menyusun tenaga kerja dalam satuan ekivalen tenaga kerja penuh. Oleh karena itu, data tenaga kerja pada tabel I-O hanya disajikan dalam bentuk jumlah tenaga kerja sektoral dengan satuan orang untuk klasifikasi 66 dan 19 sektor.

Penyusunan data tenaga kerja, antara lain dapat didasarkan dari hasil pengolahan khusus data Sensus Penduduk. Namun demikian, dari hasil pengolahan tersebut pada umumnya hanya diperoleh angka tenaga kerja yang dirinci menurut 2 digit Klasifikasi Lapangan Usaha Indonesia (KLUI). Oleh karena itu, untuk melengkapi struktur tenaga kerja pada sektor yang lebih luas harus digunakan pula data tenaga kerja yang diperoleh dari hasil berbagai Survei, seperti Sakernas, Survei Industri Besar/Sedang, Survei Industri Kecil dan Kerajinan Rumah Tangga, dan sebagainya.

\section{Koefisien Tenaga Kerja}

Koefisien tenaga kerja (labor coefficient) adalah suatu bilangan yang menunjukkan besarnya jumlah tenaga kerja yang diperlukan untuk menghasilkan satu unit keluaran (output). Sesuai dengan pengertian itu maka koefisien tenaga kerja dapat dihitung menggunakan persamaan berikut.

$$
l_{i}=\frac{L_{i}}{X_{i}}
$$

$l_{i}=$ Koefisien tenaga kerja sektor $i$

$L_{i} \quad=$ Jumlah tenaga kerja sektor $i$

$X_{i} \quad=$ Output sektor $i$

Ilustrasi perhitungan dan cara membaca koefisien tenaga kerja diuraikan pada contoh berikut.

Tabel 8 Koefisien Tenaga Kerja

\begin{tabular}{cccc}
\hline \hline Sektor & $\begin{array}{c}\text { Output } \\
(\mathrm{Rp})\end{array}$ & $\begin{array}{c}\text { Tenaga Kerja } \\
\text { (orang) }\end{array}$ & $\begin{array}{l}\text { Koefisien } \\
\text { tenaga } \\
\text { kerja }\end{array}$ \\
\hline$(1)$ & $(2)$ & \multicolumn{1}{c}{$(3)$} & $(4)$ \\
\hline 1 & 79.000 & 39.703 & 0,5026 \\
2 & 126.000 & 8.026 & 0,0637 \\
3 & 163.000 & 26.549 & 0,1629 \\
\hline Jumlah & 368.000 & 74.278 & 0,2018 \\
\hline \hline
\end{tabular}

Sebagaimana tersirat dalam persamaan, arti dari koefisien tenaga kerja sangat 
tergantung pada satuan unit yang digunakan untuk tenaga kerja dan output-nya. Dari Tabel 8 diperoleh koefisien tenaga kerja untuk sektor 1, 2, dan 3 masing-masing sebesar 0,5026, 0,0637 dan 0,1629 . Hal itu berarti bahwa untuk menghasilkan satu rupiah output di sektor 1 , 2, dan 3 masing-masing diperlukan 0,5026, 0,0637 dan 0,1629 tenaga kerja.

Koefisien tenaga kerja sektoral merupakan indikator untuk melihat daya serap tenaga kerja di masing-masing sektor. Semakin tinggi koefisien tenaga kerja di suatu sektor menunjukkan semakin tinggi pula daya serap tenaga kerja di sektor yang bersangkutan karena semakin banyak tenaga kerja yang dibutuhkan untuk menghasilkan satu unit output. Sebaliknya, sektor yang semakin rendah koefisien tenaga kerjanya menunjukkan semakin rendah pula daya serap tenaga kerjanya. Koefisien tenaga kerja yang tinggi pada umumnya terjadi di sektor padat karya sedangkan koefisien tenaga kerja rendah umumnya terjadi di sektor padat modal yang proses produksinya dilakukan dengan teknologi tinggi. Informasi tentang koefisien tenaga kerja sektoral antara lain dapat dimanfaatkan sebagai masukan dalam menyusun berbagai kebijakan dan perencanaan di bidang ketenagakerjaan.

\section{Dampak Permintaan Akhir terhadap Kebutuhan Tenaga Kerja}

Telah dijelaskan bahwa tenaga kerja merupakan salah satu faktor produksi yang balas jasa terhadapnya merupakan salah satu dari komponen input primer sehingga sesuai dengan asumsi dasar model I-O, tenaga kerja memiliki hubungan linear dengan output. Hal itu berarti bahwa naik turunnya output di suatu sektor akan berpengaruh terhadap naik turunnya jumlah tenaga kerja di sektor tersebut. Hubungan antara tenaga kerja dengan output sebenarnya telah digambarkan dalam rumus penghitungan koefisien tenaga kerja. Dalam persamaam tersebut, koefisien tenaga kerja dihitung dengan rumus $\boldsymbol{I}_{\boldsymbol{i}}=\boldsymbol{L}_{\boldsymbol{i}} / \boldsymbol{X}_{\boldsymbol{i}}$ sehingga dalam hal ini $\boldsymbol{L}_{\boldsymbol{i}}=\boldsymbol{I}_{\boldsymbol{i}} \boldsymbol{X}_{\boldsymbol{i}}$. Jika persamaan terakhir ini diuraikan untuk masing-masing sektor maka diperoleh rumus berikut.

$$
\begin{aligned}
& L_{1}=l_{1} X_{1} \\
& : \\
& L_{i}=l_{i} X_{i} \\
& L_{n}=l_{n} X_{n}
\end{aligned}
$$

Dalam bentuk matriks, persamaan di atas dapat dituliskan sebagai berikut.

$$
L=\hat{L} X
$$

dengan

$$
\mathrm{L}=\text { Matriks jumlah tenaga kerja }
$$


$\begin{aligned} \hat{L} & =\left(\begin{array}{rrrrr}l_{1} & \ldots & 0 & \ldots & 0 \\ \vdots & & \vdots & & \vdots \\ 0 & \ldots & l_{i} & \ldots & 0 \\ \vdots & & \vdots & & \vdots \\ 0 & \ldots & 0 & \ldots & l_{n}\end{array}\right) \text {, matriks diagonal koefisien tenaga kerja } \\ \mathrm{X} & =\text { Output }\end{aligned}$

Telah pula dikemukakan bahwa output yang terbentuk sebagai akibat permintaan akhir dapat dihitung dengan $X=\left(I-A^{d}\right)^{-1} F^{d}$ sehingga jika persamaan itu disubstitusikan ke dalam persamaan (11) akan diperoleh rumus berikut.

$L=\hat{L}\left(I-A^{d}\right)^{-1} F^{d}$

dengan

$L=$ Kebutuhan tenaga kerja yang dipengaruhi oleh permintaan akhir

$\hat{L}=$ Matriks diagonal koefisien tenaga kerja

$\left(I-A^{d}\right)^{-1} F^{d}=$ Output yang dipengaruhi permintaan akhir

Contoh penghitungan dampak permintaan akhir terhadap kebutuhan tenaga kerja adalah seperti uraian berikut. Dari hasil penghitungan koefisien tenaga kerja pada Tabel 8, dapat disusun matriks diagonal koefisien tenaga kerja sebagai berikut.

$\hat{L}=\left(\begin{array}{ccc}0,5026 & 0,0000 & 0,0000 \\ 0,0000 & 0,0637 & 0,0000 \\ 0,0000 & 0,0000 & 0,1629\end{array}\right)$

Dengan hasil penghitungan $\left(\mathrm{I}-\mathrm{A}^{\mathrm{d}}\right)^{-1} \mathrm{~F}^{\mathrm{d}}$ pada contoh terdahulu, dampak permintaan akhir terhadap kebutuhan tenaga kerja dapat dihitung dengan rumus berikut.

$L=\hat{L}\left(I-A^{d}\right)^{-1} F^{d}$

$L=\left(\begin{array}{ccc}0,5026 & 0,0000 & 0,0000 \\ 0,0000 & 0,0637 & 0,0000 \\ 0,0000 & 0,0000 & 0,1629\end{array}\right) \times\left(\begin{array}{rrrrr}41,0 & 2,2 & 6,4 & 2,8 & 26,6 \\ 67,9 & 5,1 & 15,8 & -1,0 & 38,1 \\ 72,0 & 20,9 & 52,1 & 0,1 & 17,8\end{array}\right)$

$48=\left(\begin{array}{rrrrr}20,0 & 1,1 & 3,2 & 1,4 & 13,4 \\ 4,3 & 0,3 & 1,0 & -0,1 & \text { J ouma } \\ 11,7 & 3,4 & 8,5 & 0,0 & 2,9\end{array}\right)$ The WMnNER, Vol. 6 No. 1, Ma ret 2005: 33-50 
Tabulasi dari hasil penghitungan tersebut dapat disajikan seperti pada Tabel 9 berikut.

Tabel 9 Kebutuhan Tenaga Kerja yang Dipengaruhi

Masing-masing Komponen Permintaan Akhir

\begin{tabular}{lrrrrrr}
\hline \hline Sektor & 301 & 302 & 303 & 304 & $305+306$ & Jumlah \\
\hline$(1)$ & $(2)$ & $(3)$ & $(4)$ & $(5)$ & $(6)$ & $(7)$ \\
\hline 1 & 20,0 & 1,1 & 3,2 & 1,4 & 13,4 & 39,1 \\
2 & 4,3 & 0,3 & 1,0 & $-0,1$ & 2,4 & 7,9 \\
3 & 11,7 & 3,4 & 8,5 & 0,0 & 2,9 & 26,5 \\
\hline Jumlah & 36,0 & 4,8 & 12,7 & 1,3 & 18,7 & 73,5 \\
\hline \hline
\end{tabular}

Dari tabel tersebut dapat dilihat bahwa penyerapan tenaga kerja yang dipengaruhi oleh konsumsi rumah tangga (301) adalah sebesar 36,0 orang dan terdiri dari tenaga kerja di sektor 1,2, dan 3 masing-masing sebesar 20,0; 4,3; dan 11,7 orang. Kebutuhan tenaga kerja yang diakibatkan oleh komponen permintaan akhir lainnya dapat dilihat dengan cara yang sama. Jika diamati menurut baris maka informasinya menunjukkan penyerapan tenaga kerja dari suatu sektor sebagai akibat masing-masing komponen permintaan akhir. Sebagai contoh, penyerapan tenaga kerja di sektor 1 yang merupakan akibat dari konsumsi rumah tangga (301) adalah sebesar 20,0 orang, konsumsi pemerintah (302) sebesar 1,1 orang, pembentukan modal tetap (303) sebesar 3,2 orang, perubahan stok (304) sebesar 1,4 orang dan ekspor barang dan jasa $(305+306)$ sebesar 13,4 orang. Penyerapan kerja untuk sektor 2 dan 3 yang diakibatkan oleh masing-masing komponen permintaan akhir dapat diamati dengan cara yang sama.

\section{PENUTUP}

Beberapa simpulan yang dapat dipaparkan sebagai berikut.

1. Pencatatan kegiatan produksi berupa transaksi antar sektor atau sub sektor disajikan dalam tabel Input -Output.

2. Tabel I-O dapat digunakan untuk struktur Input dan Output suatu sektor.

3. Tabel I-O dapat menyajikan informasi tentang Nilai Tambah Bruto (NTB).

4. Tabel I-O dapat membantu dalam menganalisis dampak suatu kebijakan terhadap output, NTB, dan kebutuhan tenaga kerja. 


\section{DAFTAR PUSTAKA}

Badan Pusat Statistik. 2003. Pendapatan Nasional Indonesia 1999 - 2002. Jakarta: BPS. . 2003. Tabel Input -Output Indonesia 2000 Jilid I. Jakarta: BPS. . 2003. Tabel Input -Output Indonesia 2000 Jilid II. Jakarta: BPS. . 2000. Teknik Penyusunan Tabel Input -Output. Jakarta: BPS. . 2000. Kerangka Teori Penyusunan Tabel Input -Output. Jakarta: BPS.

Connor, J. R. and E. W. Henry. 1975. Input Output Analysis and its Applications. New York: Hafnek Press.

Miller, Ronald E. and Peter D. B. 1985. Input-Output Analysis Foundations and Extentions. New Jersey: Prentice Hall, Inc. 